\title{
Comparison of Fatty Acid Content of Fresh and Frozen Fillets of Rainbow Trout (Oncorhynchus mykiss) Walbaum
}

\author{
Celia Chávez-Mendoza ${ }^{1 *}$, José Arturo García-Macías², Alma Delia Alarcón-Rojo², Juan \\ Ángel Ortega-Gutiérrez ${ }^{2}$, Celia Holguín-Licón ${ }^{2}$ and Gabriela Corral-Flores ${ }^{2}$ \\ ${ }^{1}$ Centro de Investigación en Alimentación y Desarrollo A.C; Unidad Delicias; Ciudad Delicias - Chihuahua - \\ México. ${ }^{2}$ Facultad de Zootecnia y Ecología; Universidad Autónoma de Chihuahua; Chihuahua - Chihuahua - \\ México
}

\begin{abstract}
The aim of this study was to evaluate and compare the percentage content of fatty acids (FA) of 54 rainbow trout fresh and frozen fillets. Frozen fillets were stored at $-15^{\circ} C$ for 45 and 90 days. Saturated (SFA), monounsaturated (MUFA), polyunsaturated (PUFA), omega-6 (n-6) and omega-3 (n-3) fatty acids were determined by gas chromatograph coupled to mass spectrometry. The results indicated that during frozen storage, SFA and MUFA content increased by 32.63 and $9.25 \%$, respectively, while PUFA content decreased by $25.3 \%, n-6$ by $12.4 \%$ and $n$ 3 by $32.55 \%$. These changes were more significant $(P \leq 0.05)$ during the first $45 d$ of storage. It was concluded that the frozen storage had a negative impact on meat quality of rainbow trout due to the reduction of PUFA, $n-3 / n-6$, polyene index and PUFA/ SFA and the increase of the SFA, and atherogenic and thrombogenic indexes, which meant a substantial loss of nutritional value in the fillets of rainbow trout.
\end{abstract}

Key words: frozen storage, rainbow trout, fatty acid profile

\section{INTRODUCTION}

In Mexico, rainbow trout fillet is the fifth largest fish produced. The main producer states are Mexico, Puebla, Veracruz, Michoacán and Chihuahua (CONAPESCA-SAGARPA 2008). In Chihuahua, an important rainbow trout producer region is located in Sierra Tarahumara Mountains because it's environmental conditions, which are optimal for their development (well oxygenated water and temperature around $20-21^{\circ} \mathrm{C}$ ). It is known that meat trout contains $2.57 \%$ of fat, $20.88 \%$ of protein (García et al. 2006) and polyunsaturated fatty acids (PUFAs), especially n3 (Harlioglu 2012), which have been related with beneficial effects on cardiovascular disease (Carrero et al. 2005), inflammatory process
(Calder 2006), and prostate, breast and colon cancer (Hardman 2004). They are important compounds for a good brain and retina function as well for cell structure (Kolanowski et al. 2007) at a recommended consumption of $650 \mathrm{mg} / \mathrm{d}$ of PUFA per week (Bermudez-Aguirre and BarbosaCánovas 2011). Meat of trout is the most important fish produced in northern Mexico. However, the farms are located far away from the market centers, which makes it important to improve the alternative preservation methods. One alternative is to freeze the fillets of this fish meat. This process results oxidation (forming FA peroxide and malonaldehyde) and hydrolysis (forming fatty acids) of highly unsaturated FA's that interact with amino acids such as lysine and methionine, which are related to the quality of

*Author for correspondence: celia.chavez@ ciad.mx 
meat (Aubourg 1999). Fatty acids produced by the hydrolysis of FA affect the quality of food, but it has been reported that the effect is reduced at lower temperature (Aubourg and Ugliano 2004). Oxidation or hydrolysis can be non-enzymatic, or catalyzed by intracellular, microbial, or digestive enzymes (Richards and Hultin 2002).

The objective of this study was to evaluate and compare the percentage of the fatty acid in fresh and frozen rainbow trout fillets stored under commercial production.

\section{MATERIALS AND METHODS}

\section{Fish Material}

Trout were harvested in an aquaculture farm located in the northwest region of Chihuahua, Mexico. The fishes were reared in a raceway production system, with a constant and abundant flow of water and ensure oxygenation and excreta disposal. Animals were fed with commercial pellets that contained $10.3 \%$ of fat (wet basis). At the end of finishing feeding period, fifty four fishes were randomly selected, then sacrificed, gutted and stored in an insulated container with ice, and transported to the laboratory for further analysis.

Rainbow trout were dissected at $24 \mathrm{~h}$ post mortem; empty body weight ranged from 224 to $334 \mathrm{~g}$, and their fillets from 145 to $224 \mathrm{~g}$. Fillets were obtained free of skin and bone, weighed, and stored in polyethylene bags. Rainbow trout fillets were randomized allocated into three treatments: fresh fillets $(n=14)$, and two frozen $\left(\right.$ at $\left.-15^{\circ} \mathrm{C}\right)$ times of storage (45 and $90 \mathrm{~d} ; \mathrm{n}=20$ in each treatment). The numbers of fillets, times of freezing, and storage temperature, were chosen based on fish farms management production where fishes were stored for a maximum of three months in commercial freezers until sold in the local market. In the present study, fillet was the experimental unit.

\section{Fatty Acids Analysis}

Before evaluation, fillets were thawed at $4^{\circ} \mathrm{C}$, ground and homogenized with a food processor (Proctor Silex). A sample of $10 \mathrm{~g}$ was taken to evaluate the lipids content following the method of Bligh and Dyer (1959); the analysis was performed in duplicate for each sample. Then the methyl esters of FAs were obtained with $12 \%$ methanolic solution of boron trifluoride (Sigma
Aldrich) (AOAC 1995). The determination of FAs concentration was evaluated by gas chromatography (Perkin Elmer XL AutoSystem), coupled to a mass spectrometer (MS: Mass Cold turbo). The system used a flame ionization detector. The temperature of the injector was $250^{\circ} \mathrm{C}$; the detector transfer line and source had a temperature of $180^{\circ} \mathrm{C}$. The split system was activated during the analysis. Temperature gradient in the column oven started at $150^{\circ} \mathrm{C}$ and remained during $2 \mathrm{~min}$ at this temperature, after that increment of $10^{\circ} \mathrm{C} / \mathrm{min}$ were performed until a $180^{\circ} \mathrm{C}$ temperature was reached. This temperature remained for $1 \mathrm{~min}$ and an increase of $3^{\circ} \mathrm{C} / \mathrm{min}$ was used until $200^{\circ} \mathrm{C}$ temperature was obtained. Finally, an increase of $40^{\circ} \mathrm{C} / \mathrm{min}$ was programmed to reach $230^{\circ} \mathrm{C}$ that was maintained for the last 5 min for each injection. Total running time per sample was $19.1 \mathrm{~min}$. The column used during this process had $30 \mathrm{~m}$ of length, $0.25 \mathrm{~mm}$ of diameter and $0.25 \mu \mathrm{m}$ of film thickness (Elite PE-225). Helium was used as carrier gas and had a flow of $1.0 \mathrm{~mL} / \mathrm{min}$, with a constant pressure of $2.5 \mathrm{psi}$. During the analysis, $1.0 \mu \mathrm{L}$ of sample was injected. For each sample obtained by the extraction of fat described previously, two subsamples were injected. In order to know the accurate retention time per fatty acid, a standard (Supelco 37 FAME MIX) was used.

\section{Calculation of Lipid Quality Index}

Polyene index (PI) was calculated using the formula proposed by Rodriguez et al. (2007): PI = [docosapentaenoic acid + docosahexaenoic acid] / (palmitic acid) Atherogenic (AI) and thrombogenic (TI) indexes were calculated according to Garafo et al. (2011):

$\mathrm{AI}=[(4 \times \mathrm{C} 14: 0)+\mathrm{C} 16: 0+\mathrm{C} 18: 0] /[\Sigma \mathrm{MUFA}+\Sigma$ $\mathrm{n}-6+\Sigma \mathrm{n}-3]$.

$\mathrm{TI}=[\mathrm{C} 14: 0+\mathrm{C} 16: 0+\mathrm{C} 18: 0] /[(0.5 \mathrm{x}$ MUFA $)+$ $(0.5 \times n-6)+(3 \times n-3)+(n-3 / n-6)]$.

\section{Statistical Analysis}

Fatty acids were determined based on the percentage of total FA identified in each meat sample. The effect of storage time was analyzed by a completely randomized design using the GLM procedures of SAS (SAS Inst. Inc. Cary, $\mathrm{NC})$. When a difference $(\mathrm{P}<0.05)$ was detected, means were separated by a Tukey comparison means test. A correlation analysis was used in order to determine the relationship among the time 
of frozen storage, fatty acids profile, and lipid quality indexes of rainbow trout fillet.

\section{RESULTS}

Fatty Acids Percentages of Frozen and Nonfrozen Rainbow Trout Fillets

Concentration of fatty acids in the fillets were affected ( $\mathrm{P} \leq 0.001)$ by storage temperature ($\left.15^{\circ} \mathrm{C}\right)$. From the day 0 to 45 , fatty acids concentration were higher $(\mathrm{P} \leq 0.05)$ in the fresh fillets than frozen fillets. However, no differences were found $(\mathrm{P}>0.05)$ from the day 45 to the day 90. Identified fatty acids concentration of fresh and frozen fillets during the 45 to 90 days is showed in Table 1.

Table 1 - Composition of fatty acids of rainbow trout (Oncorhynchus mykiss)* fillets during three times of storage $\left(-15^{\circ} \mathrm{C}\right)$.

\begin{tabular}{lccc}
\hline & \multicolumn{2}{c}{ Storage time (days) } \\
\cline { 2 - 4 } Fatty acid & $\mathbf{0}$ & $\mathbf{4 5}$ & $\mathbf{9 0}$ \\
\hline C14:0 (miristic acid) & $2.90 \pm 0.12^{\mathrm{a}}$ & $4.53 \pm 0.11^{\mathrm{b}}$ & $4.26 \pm 0.11^{\mathrm{b}}$ \\
C16:0 (palmitic acid) & $17.40 \pm 0.30^{\mathrm{a}}$ & $23.53 \pm 0.25^{\mathrm{b}}$ & $23.90 \pm 0.26^{\mathrm{b}}$ \\
C18:0 (estearic acid) & $4.07 \pm 0.08^{\mathrm{a}}$ & $4.72 \pm 0.06^{\mathrm{b}}$ & $4.81 \pm 0.07^{\mathrm{b}}$ \\
C16:1n7 (palmitoleic acid) & $5.26 \pm 0.18^{\mathrm{a}}$ & $7.16 \pm 0.15^{\mathrm{b}}$ & $7.43 \pm 0.15^{\mathrm{b}}$ \\
C18:1n9C (oleic acid) & $21.08 \pm 0.46^{\mathrm{a}}$ & $22.02 \pm 0.27^{\mathrm{a}}$ & $22.97 \pm 0.40^{\mathrm{b}}$ \\
C18:1n7C (Cis-vaccenic acid) & $2.29 \pm 0.06^{\mathrm{a}}$ & $2.67 \pm 0.05^{\mathrm{b}}$ & $2.54 \pm 0.05^{\mathrm{b}}$ \\
C20:1n11C (eicosenoic acid) & $1.55 \pm 0.07^{\mathrm{a}}$ & $1.25 \pm 0.04^{\mathrm{b}}$ & $0.95 \pm 0.06^{\mathrm{c}}$ \\
C18:2n6 (linoleic acid) & $15.74 \pm 0.32^{\mathrm{a}}$ & $13.51 \pm 0.26^{\mathrm{b}}$ & $14.08 \pm 0.26^{\mathrm{b}}$ \\
C20:2n6 (eicosadienoic acid) & $1.15 \pm 0.11^{\mathrm{a}}$ & $0.91 \pm 0.06^{\mathrm{b}}$ & $0.67 \pm 0.09^{\mathrm{b}}$ \\
C18:3n3 (alfa-linolenic acid) & $1.10 \pm 0.02^{\mathrm{a}}$ & $1.06 \pm 0.01^{\mathrm{ab}}$ & $1.02 \pm 0.02^{\mathrm{b}}$ \\
C20:3n3 (eicosatrienoic acid) & $1.67 \pm 0.12^{\mathrm{a}}$ & $1.42 \pm 0.07^{\mathrm{ab}}$ & $1.17 \pm 0.10^{\mathrm{b}}$ \\
C20:5n3 (eicosapentaenoic acid) & $5.64 \pm 0.23^{\mathrm{a}}$ & $4.88 \pm 0.13^{\mathrm{b}}$ & $4.13 \pm 0.20^{\mathrm{b}}$ \\
C22:5n3 ( docosapentaenoic acid) & $1.76 \pm 0.06^{\mathrm{a}}$ & $1.29 \pm 0.05^{\mathrm{b}}$ & $1.13 \pm 0.05^{\mathrm{c}}$ \\
C22:6n3 (docosahexaenoic acid) & $17.28 \pm 0.36^{\mathrm{a}}$ & $11.08 \pm 0.30^{\mathrm{b}}$ & $10.59 \pm 0.30^{\mathrm{b}}$ \\
\hline
\end{tabular}

* Data are expressed as percentages of total fatty acids (mean \pm standard error). ${ }^{(a, b, c)}$ values in the same row with different letter for each fatty acid indicate significant difference $(\mathrm{P} \leq 0.05)$ between frozen storage time.

In fresh fillets, the concentration of FA from highest to lowest was: oleic (C18:1n9), palmitic (C16:0) docosahexaenoic (DHA) (C22:6n3) and linoleic (C18:2n6) acid. The FA composition changed in the frozen fillets and the order was palmitic, oleic, linoleic and DHA.

Fresh fillets contained high concentrations of $n-3$, which included DHA (39\%; presenting the highest concentration of PUFA), eicosapentaenoic acid (EPA, C20:5n3; 5.64\%), docosapentaenoic acid (DPA, C22:5n3; 1.77\%), eicosatrienoic acid (C20: $3 \mathrm{n} 3 ; 1.68 \%)$, and alpha-linolenic acid (C18: 3n3; $1.09 \%)$. When fillets were frozen, $\mathrm{n}-3$ concentration decreased. At the end of the trial ( 90 d of frozen storage), DHA decreased $38.71 \%$, DPA $35.79 \%$, EPA $26.77 \%$ and alpha-linolenic acid $7.27 \%$. The higher change was found $(\mathrm{P} \leq$ $0.05)$ during the first $45 \mathrm{~d}$ of storage. The concentration of SFAs were as follows: palmitic acid (C16:0), stearic acid (C18:0) and myristic acid (C14:0) in fresh fillets $(17.4,4.07$, and $2.9 \%$; respectively). In frozen fillets (90 d of storage), myristic acid increased $(\mathrm{P} \leq 0.05)$ and was higher than palmitic and stearic $(46.89,37.35$ and $18.18 \%$, respectively).

In rainbow trout fillets, a high oleic acid concentration was found, which was $70 \%$ of total MUFAs in fresh fillets, followed by palmitoleic acid $(\mathrm{C} 16: 1 \mathrm{n} 7 ; 5.26 \%)$ cis-vaccenic acid $(\mathrm{C} 18: 1 \mathrm{n} 7 \mathrm{C} ; 2.29 \%)$ and eicosenoic acid (C20:1n11C; $1.55 \%)$. In frozen fillets, palmitoleic acid increased $41.25 \%$, oleic acid $8.96 \%$ and cisvaccenic acid $10.91 \%$; but eicosenoic acid decreased $38.70 \%$. In fresh fillets, the concentrations of PUFA were higher than MUFAs and SFA concentration, but in the frozen fillets, the concentration of PUFA decreased and both the SFA and MUFAs increased (Table 2). 
Table 2 - Fatty acid composition and lipid quality indices of rainbow trout fillets (Oncorhynchus mykiss) for three storage times $\left(-15^{\circ} \mathrm{C}\right)$.

\begin{tabular}{lccc}
\hline & \multicolumn{3}{c}{ Storage time (days) } \\
\cline { 2 - 4 } Fatty acid & $\mathbf{0}$ & $\mathbf{4 5}$ & $\mathbf{9 0}$ \\
\hline SFA & $24.67 \pm 0.38^{\mathrm{a}}$ & $32.87 \pm 0.31^{\mathrm{b}}$ & $32.72 \pm 0.33^{\mathrm{b}}$ \\
MUFA & $31.23 \pm 0.53^{\mathrm{a}}$ & $32.67 \pm 0.31^{\mathrm{b}}$ & $34.12 \pm 0.45^{\mathrm{b}}$ \\
$\mathrm{n}-6$ & $17.01 \pm 0.27^{\mathrm{a}}$ & $14.31 \pm 0.22^{\mathrm{b}}$ & $14.82 \pm 0.22^{\mathrm{b}}$ \\
$\mathrm{n}-3$ & $27.40 \pm 0.71^{\mathrm{a}}$ & $19.78 \pm 0.57^{\mathrm{b}}$ & $18.48 \pm 0.59^{\mathrm{b}}$ \\
PUFA & $44.40 \pm 0.76^{\mathrm{a}}$ & $34.09 \pm 0.61^{\mathrm{b}}$ & $33.17 \pm 0.61^{\mathrm{b}}$ \\
n3/n6 & $1.60 \pm 0.02^{\mathrm{a}}$ & $1.41 \pm 0.01^{\mathrm{b}}$ & $1.22 \pm 0.02^{\mathrm{b}}$ \\
PI & $1.30 \pm 0.03^{\mathrm{a}}$ & $0.67 \pm 0.02^{\mathrm{b}}$ & $0.60 \pm 0.02^{\mathrm{b}}$ \\
PUFA/SFA & $1.87 \pm 0.04^{\mathrm{a}}$ & $1.07 \pm 0.03^{\mathrm{b}}$ & $1.04 \pm 0.03^{\mathrm{b}}$ \\
AI & $0.44 \pm 0.01^{\mathrm{a}}$ & $0.68 \pm 0.01^{\mathrm{b}}$ & $0.69 \pm 0.01^{\mathrm{b}}$ \\
TI & $0.21 \pm 0.009^{\mathrm{a}}$ & $0.36 \pm 0.007^{\mathrm{b}}$ & $0.40 \pm 0.008^{\mathrm{b}}$ \\
\hline
\end{tabular}

*Data are expressed as percentages of total fatty acids (mean \pm standard error). SFA=saturated fatty acid; MUFA=monounsaturated fatty acids; n6=omega- 6 fatty acid; n3=omega-3 fatty acid; PUFA=polyunsaturated fatty acids, $\mathrm{PI}=$ polyene index, $\mathrm{PUFA} / \mathrm{SFA}=$ polyunsaturated fatty acids/saturated fatty acids, $\mathrm{AI}=$ atherogenic index, $\mathrm{TI}=$ thrombogenic index.

$(\mathrm{a}, \mathrm{b}, \mathrm{c})$ values in the same row with different letter for each fatty acid and lipid quality indices indicate significant difference $(\mathrm{P} \leq$ $0.05)$ between frozen storage time.

Results showed that during $90 \mathrm{~d}$ of freezing, PUFAs concentration decreased $25.29 \%, \mathrm{n}-3$

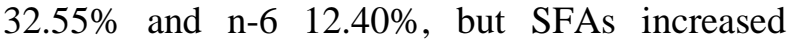
$32.63 \%$ and MUFAs $9.25 \%$. N-3/n-6 ratio is an indicator of the loss of nutritional value of the fillets. This was the case in the present study; in frozen fillets, it decreased $23.75 \%$, which was similar with PUFA/SFA ratio that decreased $44 \%$. Polyene index (PI) is an effective parameter for measuring the oxidative rancidity of fillets of rainbow trout. During frozen storage, the index declined, while atherogenic (AI) and thrombogenic (IT) indexes increased. The AI changed from 0.44 in non-frozen fillets to 0.69 in the fillets stored for $90 \mathrm{~d}$; the same happened with IT, which changed from 0.21 in non-frozen fillets to 0.40 in the frozen fillets during $90 \mathrm{~d}$.

\section{Correlation Analysis}

Frozen storage time showed correlation $(\mathrm{P} \leq 0.01)$ with all the fatty acids and indexes of lipid quality tested, except with MUFA (Table 3). The thrombogenic index (TI) showed closest correlation (0.85) with the frozen storage time. PUFA, n-3, n-6, n3/n6 and PUFA/SFA ratios showed a negative correlation $(-0.75,-0.74,-0.51$, -0.61 and -0.78 , respectively) with the frozen storage time, while SFA, polyene, thrombogenic and atherogenic indexes showed a positive correlation $(0.76, \quad 0.81, \quad 0.85$ and 0.77 , respectively) with the storage time. In general, all the fatty acids and indexes correlated $(\mathrm{P} \leq 0.01)$ between them, except MUFA, which was not related to SFA, n-6, and atherogenic index.

Table 3 - Correlation coefficients for the storage time, fatty acids and quality indexes of lipid during frozen storage of rainbow trout fillets.

\begin{tabular}{lllllllllll}
\hline Fatty acid & ST & SFA & MUFA & n6 & n3 & n3/n6 & PUFA & PUFA/SFA & PI & AI \\
\hline SFA & $0.76^{*}$ & & & & & & & & & \\
MUFA & 0.46 & 0.48 & & & & & & & \\
n6 & $-0.51^{*}$ & $-0.75^{*}$ & -0.47 & & & & & & \\
n3 & $-0.74^{*}$ & $-0.87^{*}$ & $-0.79^{*}$ & $0.55^{*}$ & & & & & \\
n3/n6 & $-0.61^{*}$ & $-0.60^{*}$ & $-0.70^{*}$ & 0.11 & $0.88^{*}$ & & & & \\
PUFA & $-0.75^{*}$ & $-0.91^{*}$ & $-0.78^{*}$ & $0.73^{*}$ & $0.97^{*}$ & $0.75^{*}$ & & & \\
PUFA/SFA & $-0.78^{*}$ & $-0.97^{*}$ & $-0.63^{*}$ & $0.73^{*}$ & $0.94^{*}$ & $0.70^{*}$ & $0.97^{*}$ & & \\
PI & $0.81^{*}$ & $-0.95^{*}$ & $-0.68^{*}$ & $0.66^{*}$ & $0.97^{*}$ & $0.80^{*}$ & $0.97^{*}$ & $0.99^{*}$ & & \\
AI & $0.77^{*}$ & $0.98^{*}$ & 0.39 & $-0.74^{*}$ & $-0.82^{*}$ & $-0.54^{*}$ & $-0.87^{*}$ & $-0.94^{*}$ & $-0.90^{*}$ & \\
TI & $0.85^{*}$ & $0.96^{*}$ & $0.65^{*}$ & $-0.67^{*}$ & $-0.95^{*}$ & $-0.75^{*}$ & $-0.97^{*}$ & $-0.97^{*}$ & $-0.97^{*}$ & $0.92^{*}$ \\
\hline
\end{tabular}

$\mathrm{ST}=$ storage time, SFA=saturated fatty acid, MUFA=monounsaturated fatty acids, n3=omega- 3 fatty acids, n6=omega- 6 fatty acids, PUFA=polyunsaturated fatty acids, PUFA/SFA=polyunsaturated fatty acids/saturated fatty acids, PI=polyene index, $\mathrm{AI}=$ atherogenic index, $\mathrm{TI}=$ thrombogenic index. $\quad *$ Correlation coefficients statistically significant $(\mathrm{P} \leq 0.01)$ 


\section{DISCUSSION}

The predominant FA's of fresh fillets in rainbow trout were oleic, palmitic, linoleic and DHA, and palmitic acid was the major SFA in fresh fillets. Similarly, oleic acid was the most important of the MUFA. These results were similar to those reported by Harlioglu (2012). Among n-3, those occurring in the highest proportions in the fresh fillets were DHA and EPA, which was similar to that obtained by Danabas (2011) in rainbow trout. These fillets had higher content of PUFA and SFA and $27.4 \%$ of $n-3$, and were similar to those results obtained by Timberg et al. (2011) in trout grown on some farms in Estonia.

When fillets were packaged and frozen $\left(-15^{\circ} \mathrm{C}\right)$, FAs quality and capacity to maintain them decreased. There were changes in their proportion; as PUFA decreased, SFA and MUFA increased. These results were in agreement to those reported by Pirestani et al. (2010) in several species of fishes from South Caspian, when fillets were stored at $-24^{\circ} \mathrm{C}$ during 6 months. Saldanha et al. (2008) found that Brazilian sardine (Sardinella brasiliensis) presented the same FAs performance when was frozen at $-18^{\circ} \mathrm{C}$ for $120 \mathrm{~d}$. Polyunsaturated fatty acids reduction was due to oxidative and hydrolytic reactions that occurred during the storage. Yi-Chen et al. (2008) showed that long hydrocarbon chains and high unsaturation of PUFA made them more susceptible to hydrolytic reactions than the SFA. This susceptibility to these reactions could be influenced by the high content of DHA (17.28\%) found in the fresh fillets during this trial, and also because fillets were not protected from light and oxygen during the storage. Because of this PUFAs are the main FAs involved in the processes of oxidation (Chen et al. 2007). It might be important to consider that temperature used in the present study could be other factor related to the quality of frozen fillets FAs. According to Yousef and Carlstrom (2003), the components of fat from the frozen fishes fillets $\left(-15^{\circ} \mathrm{C}\right)$ presented damage. This was because at this temperature, only $87 \%$ of the water was frozen, so there still were several active enzymes, which contributed to the oxidation of lipids and myofibrillar protein degradation. According to Makri (2009), during the freezing period, water crystallization produce lysis of organelles and membrane disintegration, which releases the enzymes, which are more active than when they are bound. Hsieh and Kinsella (1986) found that these enzymes catalyzed specifically the oxidation of the carbons in position 6 of both $\mathrm{n}-3$ and $\mathrm{n}-6$, producing hydroperoxides and final products as aldehydes, ketones and alcohols. Also, Burgaard and Jorgensen (2011) found that at a temperature below to $-30^{\circ} \mathrm{C}$, fillets showed better preservation of most of the quality parameters in rainbow trout fillets.

The increase in SFAs during the freezing at $-40^{\circ} \mathrm{C}$ for $180 \mathrm{~d}$ was reported by Barrero and Bello (2001) in sardine meat (Sardinella aurita), which was similar to the results obtained in this study. This performance was due the degradation of PUFAs, which generated low molecular weight compounds and possibly short chain FA. They found that EPA (C20:5n3) was the most important contributor to PUFA for the formation of low molecular weight compounds included in the SFA. The results of this study could be attributed to DHA being the most reduced PUFA, and because it was found in high amounts in the fillets used in the present study. Results showed that during the frozen storage, polyene index decreased because the relationship among the PUFA and palmitic acid decreased due to a reduction of DHA and EPA, and an increase in palmitic acid concentration. Pirestani et al. (2010) had reported similar performance in several species of fishes from the Caspian Sea, when they were frozen at $24^{\circ} \mathrm{C}$ for six months.

Nutritional value of rainbow trout fillets was measured by $n-3 / n-6$ ratio. It has been suggested that this ratio is a good standard to compare the nutritional value of oils presented in meat fish. $\mathrm{N}$ $3 / \mathrm{n}-6$ ratio of $1: 1$, or $1: 1.5$ can contribute to a healthy diet in humans (Osman et al. 2001). Results obtained for the fresh fillets (1.60) were similar to those reported by Kalyoncu et al. (2010) in the trout harvested in summer. Although, this ratio decreased during the frozen storage, which indicated an important loss of PUFAs, that was significant for human health. This phenomenon was also observed in Cobia fillets (Rachycentron canadum) that were frozen at $-18^{\circ} \mathrm{C}$ during six months (Taheri et al. 2011). In the present study, PUFA/SFA ratio was of 1.87 for the fresh fillet, which was higher than the minimum suggested (0.45) for a human healthy diet (HMSO 1994). Similar results in rainbow trout were reported by Danabas (2011). During the frozen storage, PUFA/SFA ratio decreased significantly $(\mathrm{P} \leq 0.05)$ due to loss of PUFAs, and as expected SFAs increased. Similar to these results, Pérez-Mateos 
et al. (2004) had observed that this ratio decreased during $90 \mathrm{~d}$ storage of surimi fish at $-22.3^{\circ} \mathrm{C}$.

Atherogenic and thrombogenic indexes could be used as a tool in order to compare how healthy was the lipid fraction of different foods (Rossano et al. 2005). In the present study, results for fresh fillets were lower than those from the cattle (0.72), pigs (0.69) and chicken (0.50) (Rosa and Nunes 2003). However, during the frozen storage, these tended to increase due to the loss of FA considered beneficial to health, and the increasing of atherogenic acids such as myristic acid. Correlation analysis showed that the concentration of both fatty acids and the quality indexes of lipid fraction of rainbow trout fillets depended on the frozen storage time; SFA had a positive correlation with the frozen storage time, while PUFAs were negatively related. Pirestani et al. (2010) found similar results in several species of the fishes from the Caspian Sea.

\section{CONCLUSION}

According to the results obtained in this study, frozen storage at $-15^{\circ} \mathrm{C}$ had an impact on the quality of rainbow trout. The change in the proportions of PUFA, SFA and MUFA revealed a high susceptibility to the freezing of this species. The reduction of PUFA, n3/n6 ratio, polyene index and PUFA/SFA ratio and an increase of SFA, atherogenic and thrombogenic indexes indicated a substantial loss of nutritional quality. The results suggested that the most important changes in the proportion of FAs of rainbow trout fillets occurred during the first $45 \mathrm{~d}$ of storage and apparently showed a tendency to stabilize to $90 \mathrm{~d}$. It would be important to study the effects of storage time on FAs of rainbow trout muscle over a longer period of time.

\section{ACKNOWLEDGEMENTS}

We thank Mr. J. V. Torres Muñoz professor of Faculty of Chemistry Sciences, Universidad Autonoma de Chihuahua, Chihuahua, Mexico for help with the experimental work.

\section{REFERENCES}

AOAC. Official Methods of Analysis of the Association of Official Analytical Chemists. 11 th. Edition. U.S.A. 1995.

Aubourg PS. Efecto de las alteraciones lipídicas sobre la calidad del pescado procesado. Grasas y aceites. 1999; 50: 218-224.

Aubourg PS, Ugliano M. Effect of brine pre-treatment on lipid stability of frozen horse mackerel (Trachurus trachurus). Eu. Food Res Technol. 2004; 215:91-95.

Barrero M, Bello R. Efecto de la congelación - $40^{\circ} \mathrm{C}$ en los ácidos grasos de la pulpa de sardina (Sardinella aurita) lavada con una solución de bicarbonato de sodio al 0.5\%. Revista Científica. FCV-LUZ. 2001; 9(3):230-239.

Bermudez-Aguirre D, Barbosa-Cánovas G V. Quality of selected cheeses fortified with vegetable and animal sources of omega-3. Food Sci Technol. 2011; 44:1577-1584.

Blight EG, Dyer WJA. Rapid method of total lipid extraction and purification. Can J Biochem Physiol. 1959; 37: 911-917.

Burgaard MG, Jorgensen BM. Effect of frozen storage temperature on Quality-related changes in rainbow trout (Oncorhynchus mykiss). J Aquat Food Prod Technol. 2011; 10:53-63.

Calder CP. N-3 polyunsaturated fatty acids, inflammation, and inflammatory diseases. Am J Clin Nutr. 2006; 83:1505S-1519S.

Carrero JJ, Martín-Bautista E, Baró L, Fonollá J, Jiménez J, Boza JJ, López-Huertas E. Efectos cardiovasculares de los ácidos grasos omega-3 y alternativas para incrementar su ingesta. Nutr Hosp. 2005; 20:63-69.

Chen YC, Nguyen J, Semmens K, Beamer S, Jaczynski J. Physicochemical changes in $\omega-3$ enhanced farmed rainbow trout (Oncorhynchus mykiss) muscle during refrigerated storage. Food Chem. 2007; 104:11431152.

CONAPESCA-SAGARPA. Comisión Nacional de Acuacultura y Pesca-Secretaría de Agricultura, Ganadería, Desarrollo Rural, Pesca y Alimentos. Anuario estadístico de acuacultura y pesca. Gobierno Federal. Mazatlán, Sinaloa, México. 2008.

Danabas D. Fatty acids profiles of rainbow trout (Oncorhynchus mykiss Walbaum 1972), fed with zeolite (Clinoptilolite). J Anim Plant Sci. 2011; 21(3):561-565.

Garafo A M, Vasallo-Agius R, Nengas Y, Lembo E, Rando R, Maisano R, et al. Fatty acids profile, atherogenic (IA) and thrombogenic (IT) health lipid indexes, of raw roe of blue fin tuna (Thunnus thynnus L) and their salted product "botarga". Food Nutr Sci. $2011 ; 2: 736-743$. 
García MJA, Núñez GFA, Rentería MAL, Jiménez CJA, Espinoza HMR. Calidad de canal y carne de tres variedades de trucha arcoíris Oncorhynchus mykiss (Walbaum). Hidrobiológica. 2006; 16:11-22.

Hardman EW. (N-3) fatty acids and cancer therapy. $J$ Nutr. 2004; 134: 3427S-3430S.

Harlioglu GA. Fatty acid composition, fat soluble, vitamins and cholesterol content of farmed rainbow trout (Oncorhynchus mykiss). Pakistan J Zool. 2012; 44(4)1013-1019.

HMSO. Nutritional aspects of cardiovascular disease. Report on Health and Social Subject No. 46. London, England. Department of Health. Her Majesty`s Stationery Office. 1994.

Hsieh RJ, Kinsella JE. Lipooxygenase-catalyzed oxidation of n-6 and n-3 polyunsaturated fatty acids. J Food Sci. 1986; 51:940-945.

Kalyoncu L, Yaman Y, Aktumsek A. Determination of the seasonal changes on total fatty acid composition of rainbow trout Oncorhynchus mykiss in Ivriz Dam Lake, Turkey. Afr J Biotech. 2010; 9(30):4783-4787.

Kolanowski W, Jaworska D, Weibrodt J, Kunz B. Sensory Assessment, of microencapsulated fish oil power. J Am Oil Chem Soc. 2007; 84:37-45.

Makri M. The biochemical textural and sensory properties of frozen stored $\left(-22^{\circ} \mathrm{C}\right)$ king scallop (Pecten maxinus) meats. Afr J Biotechnol. 2009; 8:3893-3903.

Osman H, Suriah AR, Law EC. Fatty acid composition and cholesterol content of selected marine fish in Malaysian water. Food Chem. 2001; 73:55-60.

Pirestani S, Sahari MA, Barzegar M. Fatty acids changes during frozen storage in several fish species from South Caspian Sea. J Agr Sci Tech. 2010; 12:321-329.

Perez-Mateos SM, Byd L, Lanier T. Stability of omega3 fatty acids in fortified surimi seafoods during chilled storage. J Agric Food Chem. 2004; 52:79447949.
Richards PM, Hultin OH. Contributions of blood and blood components to lipid oxidation in fish muscle. $J$ Agric Food Chem. 2002; 50:555-564.

Rodríguez A, Losada V, Larraín M A, Quitral V, Vinagre J, Aubourg SP. Development of lipid changes related to quality loss during the frozen storage of farmed coho salmon (Oncorhynchus kisutch). J Am Oil Chem Soc. 2007; 84:727-734.

Rosa R, Nunes ML. Nutritional quality of red shrimp, Aristeus antennatus (Risso), pink shrimp, Parapenaeus longirostris (Lucas), and Norway lobster, Nephrops norvegicus (Linnaeus). J Sci Food Agric. 2003; 84:89-94.

Rossano R, Caggiano MA, Mastrangelo L, Di Lauro R, Ungaro N, Ettorre M, et al. Proteins, fatty acids and nutritional value in the muscle of the fish species Mora moro (Risso, 1810). Mol Nutr Food Res. 2005; 49:926-931.

Saldanha T, Benass MT, Bragagnolo N. Fatty acid contents evolution and cholesterol oxides formation in Brazilian sardines followed by grilling. Food Sci Tech. 2008; 41: 1301-1309.

Taheri S, Motallelbi AA, Fazclara A, Aghababyan A. Effects of natural antioxidant (Zataria multiflora Bois) on fatty acid profile in Cobia fillets during frozen storage. Global Veterinaria. 2011; 7(5):460467.

Timberg L, Kuldjärv R, Koppel K, Paalme T. Rainbow trout and fatty acid content in Estonia. Agronomy Res. 2011; 9:495-500.

Yi-Chen Ch, Nguyen J, Semmens K, Beamer S, Jaczynski J. Chemical changes in omega-3 enhanced farmed rainbow trout (Oncorhynchus mykiss) fillets during abusive-temperature storage. Food Control. 2008; 19:599-608.

Yousef AE, Carlstrom C. Microbiología de los Alimentos. Manual de Laboratorio. Editorial Acribia. Zaragoza, España. 2003. 